\title{
Overproduction of an inducible extracellular serine protease improves biological control of Pythium ultimum by Stenotrophomonas maltophilia strain W81
}

\author{
Colum Dunne, ${ }^{1} \dagger$ Yvan Moënne-Loccoz, ${ }^{1,2} \neq$ Frans J. de Bruijn ${ }^{3}$ \\ and Fergal O'Gara'
}

Author for correspondence: Fergal O’Gara. Tel: +35321 4272097. Fax: +353214275934. e-mail: f.ogara@bureau.ucc.ie

1 BIOMERIT Research Centre, Department of Microbiology, National University of Ireland, Cork, Ireland

2 UMR CNRS Ecologie Microbienne du Sol, Université Claude Bernard (Lyon 1), 69622 Villeurbanne cedex, France

3 MSU-DOE Plant Research Laboratory and Department of Microbiology, Michigan State University, East Lansing, MI 48824, USA

\begin{abstract}
Stenotrophomonas maltophilia W81 can protect sugar beet against Pythiummediated damping-off disease through the production of an extracellular protease. Here, the proteolytic enzyme of W81 was purified by anion-exchange chromatography and characterized as a serine protease. The purified enzyme was fungicidal against Pythium ultimum in vitro. Its synthesis was inducible by casein in W81, and mutagenesis of this strain using the luciferase (luXAB) reporter transposon $\mathrm{Tn5-764cd}$ resulted in the isolation of two mutant derivatives (W81M3 and W81M4) capable of producing significantly increased levels of extracellular protease in the presence of casein. Strain W81M4 also exhibited increased chitinolytic activity. The luxAB fusions in strains W81M3 and W81M4 were highly expressed in the absence of casein but not in its presence, suggesting that the corresponding loci were involved in downregulating extracellular protease production. Extracellular protease production in the W81 wild-type strain and protease overproduction in mutants W81M3 and W81M4 were also induced in the presence of the autoclaved fungal mycelium. In soil microcosms naturally infested by Pythium spp., inoculation of sugar beet seeds with W81M3 or W81M4 resulted in improved biocontrol of Pythium-mediated damping-off disease compared with W81, and the level of protection achieved was equivalent to that conferred by chemical fungicides. The wild-type W81 and its mutant derivatives did not differ in rhizosphere colonization. Therefore, the improved biocontrol ability of W81M3 and W81M4 resulted from their capacity to overproduce extracellular serine protease.
\end{abstract}

Keywords: plant protection, phytopathogenic fungi, bacterial inoculants, serine protease, overproduction.

\section{INTRODUCTION}

Phytopathogenic fungi, such as Pythium species (oomycetes) which mediate damping-off disease, cause persistent and significant losses in annual crop yields

\footnotetext{
Present address: Department of Microbiology and National Food Biotechnology Centre, National University of Ireland, Cork, Ireland. $\ddagger$ Present address: UMR CNRS Ecologie Microbienne du Sol, Université Claude Bernard (Lyon 1), 69622 Villeurbanne cedex, France.

Abbreviations: AEBSF, 4-(2-aminoethyl)benzenesulphonyl fluoride; $\mathrm{Cm}$, chloramphenicol; Km, kanamycin; Rif, rifampicin; Sm, streptomycin; Tc, tetracycline; TNBS, 2,4,6-trinitrobenzenesulphonic acid.
}

(Agrios, 1997). Effective chemical control of pre-emergence damping-off can be achieved by the addition of synthetic fungicides to the seed prior to sowing, but these chemicals are of little use against post-emergence damping-off. Furthermore, public health and environmental concerns have focused scientific interest on the development of environmentally acceptable alternatives to chemical fungicides (Cook, 1993; Dunne et al., 1996). Biological control represents such an alternative strategy by exploiting the negative interactions that occur between disease-suppressive micro-organisms and plant pathogens (Cook et al., 1995; Handelsman \& Stabb, 1996). The development of successful biocontrol strategies, which take into consideration the complexity 
of the soil environment and generate biocontrol agents with consistent performance, relies on a thorough understanding of the interactions between the fungal pathogen, its host and the introduced biocontrol agent, and the ecological impact of the microbial inoculant in the soil environment (Dowling et al., 1996; Handelsman \& Stabb, 1996; Fedi et al., 1997; Lugtenberg \& Dekkers, 1999).

Beneficial micro-organisms of interest for biocontrol of soil-borne pathogens and pests have been identified among fungi, actinomycetes and bacteria (Becker \& Schwinn, 1993; Dunne et al., 1997a; Keel \& Défago, 1997) which produce a variety of antifungal factors such as siderophores (Becker \& Cook, 1988; O'Sullivan \& O'Gara, 1992), secondary metabolites (Dowling \& O'Gara, 1994; Nielsen et al., 1998; Bangera \& Thomashow, 1999; Delany et al., 2000) and hydrolytic enzymes (Dunne et al., 1997b, 1998; Thrane et al., 1997). Protection of plants by bacteria has also been successfully mediated by the induction of systemic plant resistance (Van Wees et al., 1997).

Recent in vitro studies have demonstrated that the exposure of selected phytopathogenic fungi to lytic enzymes such as chitinases, proteases or glucanases can result in the degradation of the structural matrix of fungal cell walls (Lorito et al., 1994; Dunne et al., 1997b). Exposure of the fungus Pythium ultimum, an oomycete lacking significant amounts of chitin in its cell wall (Mitchell \& Hurwitz, 1965; Dietrich, 1973), to endo-1,3- $\beta$-glucanase and cellulase enzymes purified from Trichoderma harzianum culture supernatants inhibited germination of encysted zoospores and prevented elongation of germ tubes (Thrane et al., 1997). The role of a proteolytic enzyme produced by the mycoparasitic fungus T. harzianum in biological control of fungal pathogens has been clearly demonstrated (Geremia et al., 1993; Haran et al., 1996). Further studies have shown that overproduction of the inducible $T$. harzianum extracellular protease resulted in enhanced biocontrol efficacy against the fungal pathogen Rhizoctonia solani (Flores et al., 1997).

The Gram-negative rod Stenotrophomonas maltophilia (formerly Xanthomonas maltophilia) is a typical soil inhabitant (Bollet et al., 1995; Berg et al., 1998) which has been the focus of scientific interest due to its potential for bioremediation (Boonchan et al., 1998) and for biological control (Berg et al., 1996; Jakobi et al., 1996; Giesler \& Yuen, 1998). S. maltophilia W81 is a sugar beet rhizosphere isolate capable of conferring protection against Py. ultimum-mediated damping-off (Dunne et al., 1997b, 1998). Mutagenesis of S. maltophilia W81 with Tn5-764cd demonstrated that this ability is mediated by proteolytic enzyme production (Dunne et al., 1997b). In Tn5-764cd-carrying mutants, lux reporter genes are under the control of resident promoters, enabling gene-expression studies by measurement of bioluminescence. Indeed, the original transposon Tn5764 (Wolk et al., 1991) and other related luciferase reporter-gene transposons have been used to identify inducible genes in Pseudomonas (Kragelund et al., 1995),
Sinorbizobium (Milcamps et al., 1998; Milcamps \& de Bruijn, 1999) and cyanobacteria (Wolk et al., 1991).

The objective of this study was to assess whether enhancement of the extracellular protease activity displayed by $S$. maltophilia W81 could result in improved suppression of Py. ultimum-mediated damping-off disease. To achieve this goal, Tn5-764cd derivatives of W81 displaying increased proteolytic activities were developed and compared with the wild-type in vitro and in natural soil microcosms grown with sugar beets.

\section{METHODS}

Micro-organisms, plasmids and growth conditions. Bacterial strains and plasmids used in the study are described in Table 1. Strain W81 was previously identified (Dunne et al., 1997b) as S. maltophilia (Palleroni \& Bradbury, 1993). S. maltophilia W81 and its mutants were routinely grown in Luria-Bertani (LB) broth (Sambrook et al., 1989) at $28^{\circ} \mathrm{C}$, Pseudomonas fluorescens strain F113Rif in sucrose asparagine (SA; Scher \& Baker, 1982) at $28^{\circ} \mathrm{C}$ and Escherichia coli in LB broth (at $37^{\circ} \mathrm{C}$ ). Antibiotics were added to growth media at the following concentrations : rifampicin (Rif), $100 \mu \mathrm{g} \mathrm{ml}^{-1}$; streptomycin $(\mathrm{Sm}), 100 \mu \mathrm{g} \mathrm{ml}^{-1}$; kanamycin $(\mathrm{Km}), 25 \mu \mathrm{g} \mathrm{ml}^{-1}$; tetracycline $(\mathrm{Tc}), 25 \mu \mathrm{g} \mathrm{ml}^{-1}$; and chloramphenicol $(\mathrm{Cm})$, $30 \mu \mathrm{g} \mathrm{ml} l^{-1}$. Bacteria were maintained in glycerol solutions at $-20^{\circ} \mathrm{C}$. Py. ultimum was obtained from the International Mycological Institute (IMI 308273) and was maintained on corn meal agar (Difco).

FPLC isolation and identification of $S$. maltophilia W81produced protease. S. maltophilia W81 and the mutant W81M1, which is unable to produce extracellular protease due to Tn5-lux insertion into the protease structural gene (Dunne et al., 1997b), were grown overnight in a minimal medium containing $0 \cdot 1 \%$ glucose and $1 \%$ skim milk, as described previously (Dunne et al., 1997b). Cultures were centrifuged at $3000 \mathrm{~g}$ and supernatants were filter-sterilized and concentrated $(\times 20)$ by filtration through Centricon spin columns with a $10 \mathrm{kDa}$ cut-off (Amicon). Concentrates were dialysed against $50 \mathrm{mM}$ Tris $/ \mathrm{HCl}(\mathrm{pH} 7 \cdot 5)$ for $4 \mathrm{~h}$ and proteins were separated on a DEAE-Sephacel anion-exchange chromatography column $(1.6 \times 20 \mathrm{~cm}$; Pharmacia $)$ equilibrated with the same buffer. Bound proteins were eluted with a gradient between 0 and $500 \mathrm{mM} \mathrm{NaCl}$ in the same Tris/ $\mathrm{HCl}$ buffer. Ten millilitre fractions were collected using the FPLC Gradifrac system (Pharmacia). Each fraction was assessed for protein content by measuring the absorbance at $280 \mathrm{~nm}$. Fractions were assessed for proteolytic enzymic activity using the fluorimetric assay described by Twinning (1984), whereby $80 \mu \mathrm{l}$ FPLC-derived samples were incubated in the presence of $80 \mu \mathrm{l}$ FITC-labelled casein at $28^{\circ} \mathrm{C}$ for $2 \mathrm{~h}$ (reaction mix $\mathrm{pH}$ 6.5). Insoluble material was then removed by centrifugation at $3000 \mathrm{~g}$. Eighty microlitres of each supernatant was then treated with $300 \mu \mathrm{l} 5 \%$ TCA. Protein was allowed to precipitate at room temperature for a minimum of $1 \mathrm{~h}$, and was then removed by centrifugation. Sixty microlitres of supernatant was neutralized by addition of $3 \mathrm{ml} 0.5 \mathrm{M}$ Tris, $\mathrm{pH} \mathrm{8.5}$. Fluorescence was measured at $490 \mathrm{~nm}$ using a Beckman DU640 spectrophotometer and cuvettes of $1 \mathrm{~cm}$ pathlength. One thousand units of enzyme activity were arbitrarily equated to 1 unit of fluorescence. The observed proteolytic activity was characterized biochemically through the addition singly of 10 individual protease inhibitors [antipain dihydrochloride, bestatin, chymostatin, E-64, leupeptin, pepstatin, phosphoramidon, 4-(2-aminoethyl)- 
Table 1. Bacterial strains and plasmids used in the study

\begin{tabular}{|c|c|c|}
\hline Strain & Relevant characteristics & Source or reference \\
\hline \multicolumn{3}{|l|}{ Strains } \\
\hline \multicolumn{3}{|l|}{ S. maltophilia } \\
\hline W81 & Wild-type, $\mathrm{Sm}^{\mathrm{r}} \mathrm{Km}^{\mathrm{r}} \mathrm{Phl}^{-} \mathrm{Hcn}^{-} \mathrm{Flu}^{-} \mathrm{Chi}^{+} \mathrm{Prt}^{+}$ & Dunne et al. (1997b) \\
\hline W81M1 & $\mathrm{Tc}^{\mathrm{r}} \mathrm{Prt}^{-}, \mathrm{Tn} 5-764 \mathrm{~cd}$ mutant of W81 & Dunne et al. (1997b) \\
\hline W81M2 & $\mathrm{Tc}^{\mathrm{r}} \mathrm{Chi}^{-}, \mathrm{Tn} 5-764 \mathrm{~cd}$ mutant of W81 & Dunne et al. (1997b) \\
\hline W81M3 & $\mathrm{Tc}^{\mathrm{r}} \operatorname{Prt}^{++}, \operatorname{Tn} 5-764 \mathrm{~cd}$ mutant of W81 & This study \\
\hline W81M4 & $\mathrm{Tc}^{\mathrm{r}} \mathrm{Chi}^{++} \mathrm{Prt}^{++}, \mathrm{Tn} 5-764 \mathrm{~cd}$ mutant of W81 & This study \\
\hline W81A1 & $\mathrm{Tc}^{\mathrm{r}} \mathrm{Chi}^{-} \mathrm{Prt}^{-}, \mathrm{Tn} 5-\mathrm{B} 50$ mutant of W81 & Dunne et al. (1997b) \\
\hline W81A1(pCU800) & $\mathrm{Tc}^{\mathrm{r}} \mathrm{Cm}^{\mathrm{r}}$, complemented mutant of W81A1 & Dunne et al. (1997b) \\
\hline \multicolumn{3}{|l|}{ Ps. fluorescens } \\
\hline F113Rif & $\mathrm{Phl}^{+} \mathrm{Hcn}^{+} \mathrm{Flu}^{+} \mathrm{Rif}^{\mathrm{r}}$ & Carroll et al. (1995) \\
\hline \multicolumn{3}{|l|}{ E. coli } \\
\hline HB101 & recA hsdB hsdM strA pro leu thi & $\begin{array}{l}\text { Boyer \& Roulland- } \\
\text { Dussoix (1969) }\end{array}$ \\
\hline DH5 $\alpha$ & $\phi 80 \operatorname{lacZ} \Delta \mathrm{M} 15 \Delta(\operatorname{lac} Z Y A-\arg F) U 169$ hsdR17 recA1 endA1 thi-1 & Sambrook et al. (1989) \\
\hline \multicolumn{3}{|l|}{ Plasmids } \\
\hline pCU800 & IncQ $\mathrm{Cm}^{\mathrm{r}} \mathrm{Tc}^{\mathrm{r}}$ broad-host-range cosmid pSUP106 with a $15 \mathrm{~kb}$ insert from W81 & Dunne et al. (1997b) \\
\hline pRK2013 & $\mathrm{Mob}^{+} \mathrm{Tra}^{+} \mathrm{Km}^{\mathrm{r}}$ & Ditta et al. (1980) \\
\hline pRL764cd & $\mathrm{Tc}^{\mathrm{r}} \mathrm{LuxAB}^{+}$ & Dunne et al. (1997b) \\
\hline
\end{tabular}

benzenesulphonyl fluoride (AEBSF), EDTA and aprotinin; Boehringer Mannheim], each of which is capable of inhibiting the activity of specific families of proteolytic enzyme, and the subsequent assessment of the remaining enzymic activity, as described above. Each protease inhibitor was tested twice.

Susceptibility of Py. ultimum to W81-produced protease in vitro. Py. ultimum mycelium was prepared by growth in LB broth as described previously (Dunne et al., 1997b). Collected mycelium was then resuspended in fresh LB broth containing commercial protease (EC 3.4.21.14, 0.5-1.0 units $\mathrm{ml}^{-1}$; Sigma) or FPLC-derived samples of wild-type W81 or W81M1 supernatant and incubated for $48 \mathrm{~h}$ at $28{ }^{\circ} \mathrm{C}$. Since W81 is chitinase-positive, the experiment was also performed using commercial chitinase from Streptomyces griseus (EC 3.2.1.14, 0.5-1.0 units $\mathrm{ml}^{-1}$; Sigma).

As described previously (Dunne et al., 1997b), treated mycelium was examined microscopically, both in wet mounts and following staining with anionic dyes. Remaining samples were assayed for fungal growth, as follows: Pythium mycelium was washed in quarter-strength Ringer's solution and placed in the centre of LB agar, potato dextrose agar (PDA; Oxoid), malt extract agar (MEA; Oxoid) or nutrient agar (NA; Oxoid). Growth of the fungus was assessed following incubation of the plates for $7 \mathrm{~d}$ at $28^{\circ} \mathrm{C}$. In all assays, untreated Pythium mycelium was used as a control and fungal growth was observed on each medium tested.

Genetic manipulations. Mobilization of plasmids between $E$. coli and S. maltophilia W81 was performed using the helper plasmid pRK2013 (Ditta et al., 1980). Transformation of E. coli $\mathrm{DH} 5 \alpha$ was performed using the standard $\mathrm{CaCl}_{2}$ heatshock method. Recombinant DNA manipulations were performed as outlined by Sambrook et al. (1989). All digestions and ligations were performed using enzymes from Promega or Boehringer Mannheim.

Tn5-764cd mutagenesis of the $\mathrm{Sm}^{\mathrm{r}}$ strain W81 was performed following procedures previously described by Kragelund et al.
(1995), using pRL764cd. Tn5-764cd is a tetracycline-resistant derivative of pRL764 (Wolk et al., 1991) developed to overcome the natural resistance of strain W81 to kanamycin (Dunne et al., 1997b). The resulting Tn5-764cd insertion derivatives $\left(\mathrm{Sm}^{\mathrm{r}} \mathrm{Tc}^{\mathrm{r}}\right)$ were screened for chitinolytic and proteolytic activities on solid media, as follows. Chitinolytic activity was assessed qualitatively using the solid chitin minimal medium described by Dunne et al. (1997b), and proteolytic activity was observed on plates containing skim milk $\left(100 \mathrm{~g} \mathrm{l}^{-1}\right)$, yeast extract $\left(1.5 \mathrm{~g} \mathrm{l}^{-1}\right)$ and technical agar (15 $\left.\mathrm{g} \mathrm{l}^{-1}\right)$. Bacteria were either inoculated directly onto the solid media or, alternatively, $100 \mu \mathrm{l}$ filter-sterilized supernatant from bacterial cultures grown in SA or LB, obtained after concentration $(\times 500)$ using an Amicon ultra-filtration unit, were spotted onto the plates. These plates were incubated overnight at $28^{\circ} \mathrm{C}$. Both chitin- and skim milk-containing plates are opaque and enzymic activity was identified by the development of a zone of clearing (halo) surrounding the colonies and the cell-free supernatant spots. Mutants capable of overproducing protease (W81M3) or both chitinase and protease (W81M4) were identified.

Quantitative determination of extracellular chitinolytic and proteolytic activities. Chitinolytic and proteolytic activities were also quantified biochemically. Extracellular chitinolytic activity was determined colorimetrically, as described by Boller \& Mauch (1988). Extracellular proteolytic activity was measured using a modification (described by Dunne et al., 1997b) of the colorimetric procedure of McKellar (1981), whereby precipitated material resulting from proteolysis of Hammersten casein (BDH) buffered with $1 \mathrm{M}$ MOPS and $15 \mathrm{mM} \mathrm{CaCl}_{2}$, pH $6 \cdot 5$ reacts with $0 \cdot 1 \%$ 2,4,6-trinitrobenzenesulphonic acid (TNBS), allowing colour development. Alternatively, the fluorimetric assay described by Twinning (1984) was used (see above).

Induction of bioluminescence and/or proteolytic activity in Tn5-764cd mutants of S. maltophilia W81. Mutants of $S$. maltophilia W81 carrying Tn5-lux fusions were grown at 
$28{ }^{\circ} \mathrm{C}$ for $12 \mathrm{~h}$ in either LB broth or a minimal medium containing $0 \cdot 1 \%$ glucose (Dunne et al., 1997b), in the presence of chitin, casein or Py. ultimum mycelium, to assess the latter for possible induction of bioluminescence or proteolysis. Proteolysis was measured using Twinning's fluorimetric assay (see above).

Bioluminescence was first assayed by placing $50 \mu \mathrm{l}$ decylaldehyde (Sigma) on the inside cover of a glass Petri dish, which was then used to cover colony-containing plates for a period of $60 \mathrm{~s}$. Luminescent colonies were then visualized using a Hamamatsu photonic camera system (model C196620; Photonic Microscopy) for a further $60 \mathrm{~s}$, as described by Kragelund et al. (1995). Bioluminescence was then measured with a Lumac Biocounter M1500 by placing $2 \mathrm{ml}$ bacterial culture into a glass cuvette and quantifying the resulting luminescence following the addition of $100 \mu \mathrm{l} 5 \% \mathrm{n}$-decylaldehyde in ethanol.

Growth rate determinations. Growth rates of $S$. maltophilia W81 and its mutant derivatives were determined in liquid LB incubated with aeration at $28^{\circ} \mathrm{C}$. At hourly intervals, $1 \mathrm{ml}$ samples of the cultures were aseptically removed, $\mathrm{OD}_{600}$ measured and cell numbers determined on solid LB containing Sm or Sm plus Tc for wild-type W81 or its mutant derivatives, respectively.

Soil microcosm experiments. The ability of wild-type W81 and its mutant derivatives to protect sugar beet from dampingoff disease was investigated in natural soil microcosms prepared using a sandy-loam soil obtained from the surface horizon of a field located near Brinny (Co. Cork, Ireland). The soil chosen is naturally infested by Pythium spp. [ $>1000$ propagules (g soil) ${ }^{-1}$ detected using a Pythium-selective medium (Jeffers \& Martin, 1986)] and conducive to disease development. Soil handling and microcosm preparation (140 g soil per pot) were as described by Fenton et al. (1992) and Moënne-Loccoz et al. (1999). Sugar beet seeds (cv. Accord) were inoculated by dipping them in cell suspensions of the bacteria studied (approx. $10^{6}$ c.f.u. per seed). The latter included wild-type W81; W81M1, deficient in protease production; W81M2, deficient in chitinase production; W81M3, capable of protease overproduction; W81M4, capable of overproducing both chitinase and protease; W81A1, unable to produce either lytic enzyme; W81A1(pCU800), with restored lytic enzyme production; and the biocontrol agent Ps. fluorescens F113Rif (Carroll et al., 1995; Moënne-Loccoz et al., 1998). The untreated control consisted of seeds dipped in quarter-strength Ringer's solution. The commercial control involved treating seeds with a solution containing the synthetic fungicides Previcur N (propamocarb; Schering) at $20 \mathrm{ml}(\mathrm{kg}$ seed $)^{-1}$ and thiram at $7.5 \mathrm{~g}(\mathrm{~kg} \text { seed })^{-1}$. Nine seeds were sown per pot. Soil water content was adjusted to $70 \%$ saturation of the soil porosity every $3 \mathrm{~d}$ by spraying with distilled water. The pots were incubated in a growth chamber $\left(12{ }^{\circ} \mathrm{C} ; 16 \mathrm{~h}\right.$ photoperiod).

Infection of seeds by Pythium spp. was assessed at $1 \mathrm{~d}$ after sowing, as previously described (Dunne et al., 1997b). Sugar beet seeds were removed from soil, washed in sterile quarterstrength Ringer's solution and incubated on the Pythiumselective agar of Jeffers \& Martin (1986) at $28^{\circ} \mathrm{C}$. At 48 h the seeds were scored for the presence of Pythium spp. The percentage of plant emergence was determined at $28 \mathrm{~d}$. Colonization of the sugar beet rhizosphere by the seed inoculants was assessed by colony counts on LB containing Sm plus Km (for wild-type W81), LB containing Sm plus Km plus Tc (for mutant derivatives of W81), or SA containing Rif (for F113Rif). Extracts were made, each from a whole root system with its closely adhering soil (Dunne et al., 1998). No colonies were found on the selective media when studying plants from the untreated control (detection limit of $10^{2}$ c.f.u. per root system).

Statistical tests. All in vitro experiments were performed with three replicates of each treatment and were repeated at least three times. The effects of treatments were studied by analysis of variance and Fisher's LSD tests $(P<0 \cdot 05)$.

A randomized complete block design was used for the soil microcosm experiments, which were performed on three independent occasions. Seed infection by Pythium spp. was studied using ten seeds from each of three replications for each treatment. Plant emergence was investigated using nine replications. Each replication of each treatment consisted of one pot with nine seeds per pot. Six root systems were used to assess rhizosphere colonization of each strain at each sampling time, as described previously (Moënne-Loccoz et al., 1999). Percentages were arcsin-transformed and colony counts were log-transformed prior to analysis. Within each run of the experiment, analysis of variance was performed at each sampling time using the General Linear model procedures of the Statistical Analysis System (SAS Institute Inc.). When appropriate, differences between treatments were studied using Fisher's LSD test. All analyses were performed at $P=$ 0.05 level. Similar results were obtained each time the soil microcosm experiments were completed and representative results (obtained in one of the three runs) are shown in Fig. 3.

\section{RESULTS}

\section{Purification and characterization of the S. maltophilia W81 extracellular protease}

The extracellular protease synthesized by S. maltophilia W81 was purified by DEAE-Sephacel anion-exchange chromatography. Protein content analysis resulted in the identification of two distinct peaks (Fig. 1a). Only fractions corresponding to the first peak (i.e. fractions 3-5) displayed proteolytic activity when assayed with FITC-labelled casein (Fig. 1b). Similar procedures were followed using strain W81M1, a transposon-induced mutant of W81 deficient in extracellular protease activity (Dunne et al., 1997b). Its protein profile was similar to that of the wild-type strain, except for the distinctive first peak present in the W81 fractions which was absent in the mutant strain (Fig. 1a). Furthermore, none of the fractions obtained from strain W81M1 culture supernatant exhibited proteolytic activity (Fig. 1b). The extracellular proteolytic activity of the wild-type strain was characterized using a series of ten specific protease inhibitors. Only one of these inhibitors, AEBSF, affected the FITC-labelled-casein-degrading activity of the enzyme. This indicates that this extracellular protease produced by W81 is a serine protease.

\section{Effect of the S. maltophilia W81-produced serine protease on Py. ultimum in vitro}

Concentrated cell-free culture supernatant of strain W81 (but not that of mutant strain W81M1) caused degradation of the cell wall of Py. ultimum (Dunne et al., $1997 b)$. In the current study, we found that exposure of Py. ultimum mycelium to purified W81 serine protease resulted in cell-wall degradation (data not shown). Subsequent washing and plating of the treated mycelium 

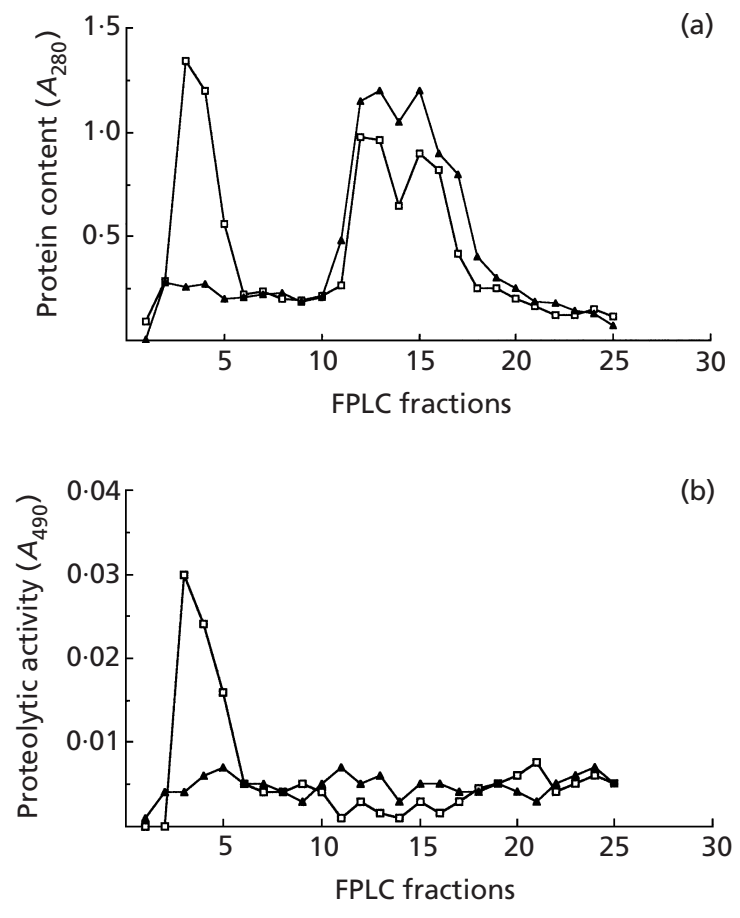

Fig. 1. Purification of a proteolytic enzyme by DEAE-Sephacel anion-exchange chromatography from culture supernatant of S. maltophilia W81. Analysis of the protein content of the collected FPLC fractions (a) shows that an obvious peak (fractions 3, 4 and 5) present with wild-type W81 ( $\square$ ) is absent with protease-deficient mutant W81M1 (A). Fluorimetric assessment of the proteolytic activity of the collected fractions (b) demonstrates that enzymic activity is associated only with this peak.

on several solid media where Py. ultimum is routinely grown indicated that the effect of the serine protease was fungicidal. Degradation of the fungal cell wall and irreversible loss of growth ability were also observed when the experiment was performed using a commercial protease. In contrast, the non-proteolytic FPLC fractions obtained from strain W81, as well as all fractions from the protease-negative mutant strain W81M1, had no effect on the fungus. This confirms that the effect of W81 on Py. ultimum was mediated by its extracellular protease.

\section{Transposon-induced mutants of S. maltophilia W81 displaying increased extracellular protease production}

Mutants of strain W81 overproducing extracellular protease were obtained by mutagenesis with the transposon $\mathrm{Tn} 5-764 \mathrm{~cd}$. Approximately $15000 \mathrm{Tc}^{\mathrm{r}}$ colonies were screened on solid medium containing casein and mutants with increased extracellular protease activity were apparent from the diameter of the haloes of casein hydrolysis surrounding colonies (Fig. 2a). The mutant strains W81M3 and W81M4 produced zones of hydrolysis with diameters approximately three times greater than that of the halo around the wild-type strain W81. When the colorimetric TNBS assay was used, it
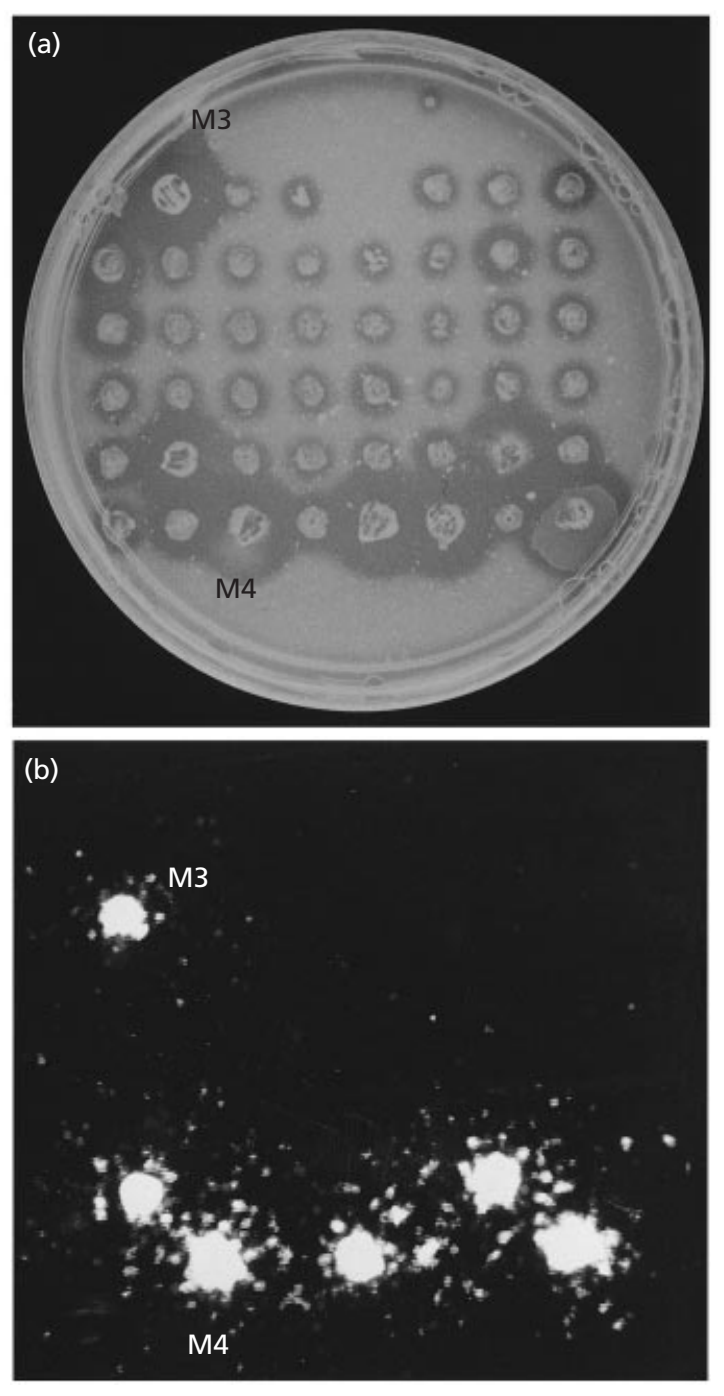

Fig. 2. Proteolytic activity and bioluminescence of transposoninduced mutants of S. maltophilia W81. Mutants W81M3 and W81M4 capable of increased protease production are apparent in (a) as larger haloes caused by increased degradation of casein. These mutants are luminescent in the absence of a proteinaceous inducer (b) but are repressed in the presence of casein or Py. ultimum mycelium.

appeared that strains W81M3 and W81M4 produced approximately three times the amount of extracellular protease synthesized by strain W81 (Table 2). Strain W81M4 also displayed enhanced chitinase activity on chitin plates when compared with W81 (data not shown). Fluorimetric quantification experiments demonstrated that mutant W81M4 produced approximately three times as much chitinase as the wild-type strain (Table 2).

Mutant strains W81M3 and W81M4, in addition to two other Tn5-764cd mutants of W81 obtained in a previous investigation (W81M1 and W81M2; Dunne et al., 1997b), were compared by Southern hybridization, using ${ }^{35}$ S-labelled Tn5-764cd DNA as a probe (as described by Dunne et al., 1997b). This experiment demonstrated 
Table 2. Growth and extracellular proteolytic and chitinolytic activities exhibited in vitro by S. maltophilia W81 and its mutant derivatives

Standard deviations are given in parentheses. Within each column, values followed by a different letter are significantly different according to Fisher's LSD test $(P<0 \cdot 05)$.

\begin{tabular}{|c|c|c|c|c|c|}
\hline \multirow[t]{2}{*}{ Strains } & \multirow{2}{*}{$\begin{array}{l}\text { Growth rate in LB } \\
\text { broth }\left(\mathbf{h}^{-1}\right)^{*}\end{array}$} & \multicolumn{2}{|c|}{ Protease activity } & \multicolumn{2}{|c|}{ Chitinase activity } \\
\hline & & Units $\dagger$ & $\%$ of wild-type level & Units $\ddagger$ & $\%$ of wild-type level \\
\hline W81 & $1 \cdot 28(0 \cdot 22)$ & $6 \cdot 5(0 \cdot 6)^{a}$ & & $59 \cdot 6(8 \cdot 0)^{a}$ & \\
\hline W81A1 & $1 \cdot 18(0 \cdot 16)$ & $0 \cdot 8(0 \cdot 2)^{b}$ & $12(3)^{a}$ & $2 \cdot 5(1 \cdot 2)^{b}$ & $4(2)^{a}$ \\
\hline W81A1(pCU800) & $1 \cdot 26(0 \cdot 19)$ & $6 \cdot 4(0 \cdot 4)^{a}$ & $99(6)^{b}$ & $57 \cdot 3(8 \cdot 0)^{a}$ & $96(13)^{b}$ \\
\hline W81M1 & $1 \cdot 17(0 \cdot 13)$ & $0 \cdot 9(0 \cdot 6)^{b}$ & $15(9)^{a}$ & $61 \cdot 3(3 \cdot 1)^{a}$ & $103(5)^{b}$ \\
\hline W81M2 & $1 \cdot 27(0 \cdot 17)$ & $7 \cdot 3(0 \cdot 8)^{a}$ & $112(12)^{b}$ & $0^{b}$ & $0^{a}$ \\
\hline W81M3 & $1 \cdot 13(0 \cdot 21)$ & $19 \cdot 2(1 \cdot 8)^{c}$ & $295(28)^{c}$ & $67 \cdot 7(3 \cdot 4)^{a}$ & $114(6)^{b}$ \\
\hline W81M4 & $1.09(0 \cdot 21)$ & $18 \cdot 3(1 \cdot 2)^{c}$ & $282(19)^{c}$ & $178 \cdot 0(3 \cdot 3)^{c}$ & $299(6)^{c}$ \\
\hline
\end{tabular}

*All growth rates were statistically identical.

† TNBS colorimetric assay described by McKellar (1981): one unit of activity corresponds to $1 \mathrm{nmol}$ glycine equivalents released (ml cellfree supernatant $)^{-1} \mathrm{~min}^{-1}$.

$\ddagger$ Unit of activity defined as $1000 \times A_{585}(\mathrm{ml} \text { cell-free supernatant })^{-1} \mathrm{~h}^{-1}$, as described by Dunne et al. (1997b).

Table 3. Effect of casein, colloidal chitin and autoclaved Py. ultimum mycelium on protease production by $S$. maltophilia wild-type W81 and its mutants and luminescence of Tn5-764cd-induced derivatives of W81

Standard deviations are given in parentheses. Within each column, values followed by a different lower case letter are significantly different according to Fisher's LSD test $(P<0 \cdot 05)$. Within each row, values for protease activity and for luminescence followed by a different upper case letter are significantly different according to Fisher's LSD test $(P<0 \cdot 05)$.

\begin{tabular}{|c|c|c|c|c|c|c|c|c|}
\hline \multirow[t]{2}{*}{ Strains } & \multicolumn{2}{|c|}{ Control } & \multicolumn{2}{|c|}{ In presence of casein } & \multicolumn{2}{|c|}{ In presence of colloidal chitin } & \multicolumn{2}{|c|}{$\begin{array}{l}\text { In presence of autoclaved } \\
P y \cdot \text { ultimum mycelium }\end{array}$} \\
\hline & $\begin{array}{l}\text { Protease } \\
\text { activity" }\end{array}$ & Luminescence $\dagger$ & $\begin{array}{l}\text { Protease } \\
\text { activity* }\end{array}$ & Luminescence $\dagger$ & $\begin{array}{l}\text { Protease } \\
\text { activity* }\end{array}$ & Luminescence $†$ & $\begin{array}{l}\text { Protease } \\
\text { activity* }\end{array}$ & Luminescence $†$ \\
\hline W81 & $81(12)^{A a}$ & & $141(15)^{B a}$ & & $90(11)^{A a}$ & & $123(6)^{B a}$ & \\
\hline W81A1 & $8(3)^{A b}$ & & $5(1)^{A b}$ & & $8(1)^{A b}$ & & $7(2)^{A b}$ & \\
\hline $\begin{array}{l}\text { W81A1 } \\
\text { (pCU800) }\end{array}$ & $84(11)^{A a}$ & & $138(11)^{B a}$ & & $83(9)^{A a}$ & & $119(10)^{B a}$ & \\
\hline W81M1 & $7(3)^{A b}$ & $79(22)^{A a}$ & $11(2)^{A b}$ & $17900(100)^{B a}$ & $7(4)^{A b}$ & $70(16)^{A a}$ & $5(1)^{A b}$ & $5380(990)^{C a}$ \\
\hline W81M2 & $75(14)^{A a}$ & $57(27)^{A a}$ & $129(11)^{B a}$ & $39(17)^{A b}$ & $65(9)^{A a}$ & $48(18)^{A a}$ & $113(6)^{B a}$ & $34(15)^{A b}$ \\
\hline W81M3 & $88(11)^{A a}$ & $14900(1000)^{A b}$ & $254(23)^{B c}$ & $435(103)^{B c}$ & $97(14)^{A a}$ & $12500(1500)^{A b}$ & $167(16)^{C c}$ & $1300(200)^{C c}$ \\
\hline W81M4 & $91(12)^{A a}$ & $22300(1300)^{A c}$ & $229(22)^{B c}$ & $587(121)^{B c}$ & $147(11)^{C c}$ & $4100(970)^{C c}$ & $196(19)^{B c}$ & $754(158)^{B d}$ \\
\hline
\end{tabular}

*FITC-labelled casein assay described by Twinning et al. (1984): one unit of fluorescence arbitrarily equated to 1000 units of protease activity.

†Luminescence detected $\min ^{-1}$ in the presence of $100 \mu 15 \%$ n-decylaldehyde.

that the corresponding sites of transposon insertion were located in four different regions of the genome (data not shown). This suggests that each of the mutants corresponds to the disruption of a distinct gene. Apart from the observed differences in levels of lytic enzyme production, the four Tn5-764cd mutants of strain W81 did not differ from the wild-type on the basis of growth in LB broth (Table 2) or when compared using a variety of biochemical tests (aerobic acidification of glucose; production of catalase, oxidase, gelatinase, DNAase; assimilation of acetate, citrate, malate, glucose, mannose, maltose, $\mathrm{N}$-acetylglucosamine and maltose; data not shown).

\section{Induction of extracellular protease synthesis in S. maltophilia W81 and its mutant derivatives}

The successful use of biocontrol agents requires a good understanding of patterns of expression of the corresponding biocontrol traits. In the case of extracellular 
lytic enzymes, a key issue may be how the presence of inducers or target organisms influences enzyme synthesis. Under in vitro conditions, extracellular protease production by wild-type W81 increased in a similar fashion in the presence of casein or autoclaved $P y$. ultimum mycelium (Table 3), as observed in $T$. harzianum (Geremia et al., 1993; Flores et al., 1997). Similar results were obtained with the chitinase-negative mutant W81M2 and the W81A1 mutant strain carrying the plasmid pCU800 which restores lytic enzyme production (Dunne et al., 1997b). Casein and autoclaved fungal mycelium did not induce proteolytic activity in the extracellular-protease-deficient mutants W81A1 and W81M1 (Dunne et al., 1997b). In the absence of appropriate inducer, the two Tn5-764cd-induced mutants W81M3 and W81M4 produced similar amounts of extracellular protease as the wild-type W81 strain (Table 3), indicating that overproduction of the enzyme occurred only after induction. The increase in extracellular protease production by these mutant strains in the presence of autoclaved Py. ultimum mycelium was less than that induced by casein. In contrast with studies on the wild-type W81 strain, an increase in extracellular protease production (although less than with autoclaved fungal mycelium) was also observed when strain W81M4 was incubated in the presence of colloidal chitin (Table 3).

\section{Effect of casein, chitin and autoclaved Py. ultimum mycelium on expression of loci inactivated by Tn5-764cd in mutants of S. maltophilia W81}

Transposition of $\operatorname{Tn} 5-764 \mathrm{~cd}$ results in the generation of transcriptional fusions, in which the promoterless $\operatorname{lu} x A B$ reporter gene cassette is regulated by resident promoters. We exploited this property to determine the effect of casein, chitin and autoclaved Py. ultimum mycelium on the expression of the loci inactivated by the transposon in mutant strains W81M1, W81M2, W81M3 and W81M4, with the objective of gaining insight into the regulation of extracellular protease production in strain W81. Bioluminescence data indicated that the W81M1 protease structural gene inactivated by $T n 5-764 \mathrm{~cd}$ was expressed at a much higher level in the presence of casein or autoclaved fungal mycelium (Table 3). In contrast, the lux gene fusions in the mutants W81M3 and W81M4 were significantly less luminescent in the presence of casein or autoclaved Pythium mycelium than in their absence (Fig. 2b and Table 3). Strain W81M4 also displayed reduced luminescence when incubated in the presence of chitin.

\section{Biocontrol of Pythium-mediated damping-off of sugar beet by S. maltophilia W81 and its mutant derivatives in natural soil microcosms}

In soil microcosms naturally infested by Pythium spp., inoculation of sugar beet seeds with wild-type W81, the chitinase-negative mutant W81M2 or the reference biocontrol agent Ps. fluorescens F113R if (Carroll et al., 1995; Moënne-Loccoz et al., 1998) increased the per-

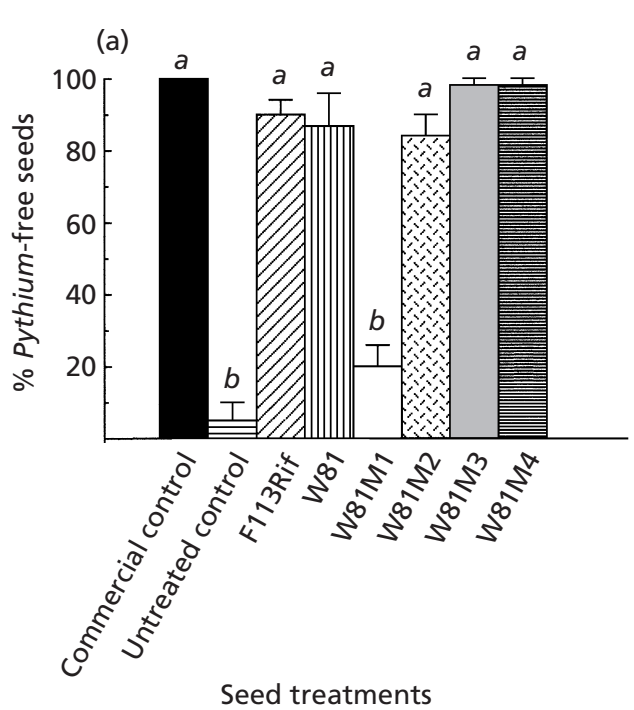

(b)

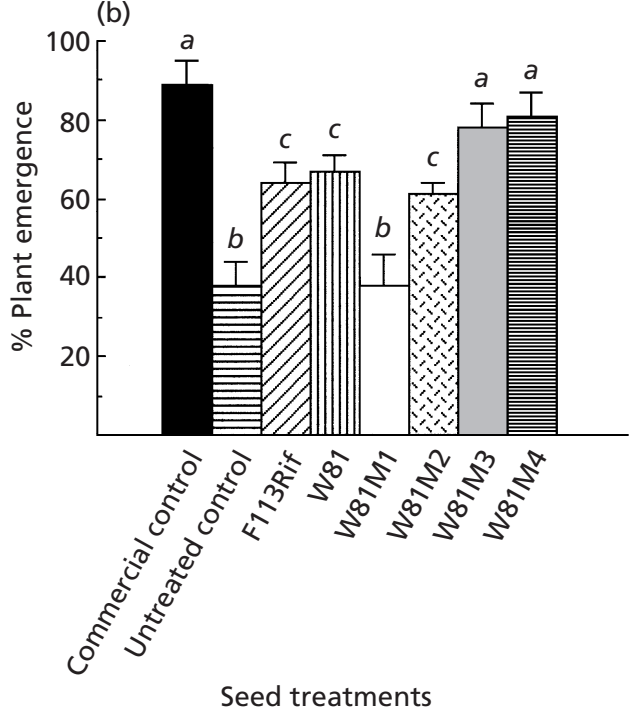

Fig. 3. Effect of S. maltophilia W81 and its mutant derivatives on damping-off disease of sugar beet in natural soil microcosms prepared with soil naturally infested by Pythium spp. A commercial treatment (i.e. synthetic fungicides Previcur $\mathrm{N}$ and thiram), an untreated control (i.e. seeds soaked in quarterstrength Ringer's solution), and the effect of the biocontrol agent Ps. fluorescens F113Rif were also studied. The percentage of seeds free from colonization by Pythium spp. at $1 \mathrm{~d}$ after sowing is shown in (a). The percentage emergence of sugar beet at $28 \mathrm{~d}$ after sowing is given in (b). Error bars represent standard deviations. In (a) and in (b), bars headed by a different letter are significantly different according to Fisher's LSD test $(P<0.05)$.

centage of seeds not colonized by Pythium spp. from $5 \%$ (in the untreated control) to between $80 \%$ and $90 \%$ at $1 \mathrm{~d}$ after sowing (Fig. 3a). The percentage of Pythiumfree seeds was $98 \%$ or higher when seeds were inoculated with W81M3 or W81M4 or treated with chemical fungicides (commercial control). As in a previous investigation (Dunne et al., 1997b), this beneficial effect 
was not found in the protease-negative W81M1 treatment. The percentage of plants that emerged was assessed $28 \mathrm{~d}$ after sowing, and results showed that the two mutants W81M3 and W81M4 provided better protection against disease than W81, W81M2 or F113R if (Fig. 3b). Furthermore, only the W81M3 and W81M4 treatments achieved levels of plant protection as high as that conferred by the use of chemical fungicides.

Colonization of the rhizosphere of sugar beet by the seed inoculants was assessed by colony counts on selective media throughout the $28 \mathrm{~d}$ experiment. At each sampling time, the population sizes of the strains in the rhizosphere were statistically identical (approx. $10^{4 \cdot 5}$ c.f.u. per root system at $28 \mathrm{~d}$ ). In each inoculated treatment, ten colonies were chosen at random from the plates used for counts at each sampling time and their phenotype was investigated. All exhibited similar extracellular chitinase and protease activities on plates as compared with those of the corresponding inoculants. No colonies were found on the selective media when studying plants from the untreated control (detection limit of $10^{2}$ c.f.u. per root system).

\section{DISCUSSION}

In this study, an extracellular protease produced by $S$. maltophilia W81 was purified by DEAE-Sephacel anionexchange chromatography using a protocol similar to that employed by Thrane et al. (1997) to isolate a Pythium-affecting endo-1,3- $\beta$-glucanase from $T$. harzianum. The purified enzyme was characterized biochemically as a serine protease, in agreement with previous results of amino acid sequence analysis suggesting that the W81 extracellular protease shares significant homology with an acrosin trypsin-like serine peptidase (S12968) (Dunne et al., 1997b).

Since extracellular protease production appears to be responsible for the ability of strain W81 to control the extent of Pythium-mediated damping-off of sugar beet (Dunne et al., 1997b, 1998), we hypothesized that superior biocontrol activity may be obtained by increasing production levels of this protease. In the current study, mutagenesis with the transposon Tn5-764cd resulted in the isolation of W81M3 and W81M4, two mutants producing approximately three times more extracellular protease than the wild-type W81 strain in the presence of casein (Table 2). Mutant W81M4 also displayed enhanced chitinolytic activity compared to W81, a property that may be useful for biocontrol of chitinase-sensitive pathogens and parasites of plants (Cronin et al., 1997) but not of Pythium spp. (Dunne et al., 1997b). A similar strategy of transposon mutagenesis resulted in the generation of mutants of biocontrol agent Ps. fluorescens CHA0 capable of overproducing the antifungal compound pyoluteorin (Schnider et al., 1995).

Overproduction of extracellular protease by W81M3 and W81M4 did not take place in the absence of inducer. However, both W81M3 and W81M4 displayed strong luminescence under non-inducing conditions but not in the presence of casein (Table 3), suggesting that the genes inactivated in these mutants may be involved in down-regulating extracellular protease production. In the case of W81M4, which also overproduces chitinase, the presence of colloidal chitin caused induction of extracellular protease production, although at significantly lower levels than that caused by casein. Therefore, the putative regulatory locus inactivated in W81M4 may be involved in down-regulation of both extracellular protease and chitinase production.

Tn5-764cd was used previously to generate mutant W81M1 deficient in extracellular protease synthesis (Dunne et al., 1997b). Here, W81M1 exhibited strong luminescence in the presence of casein but not in its absence (Table 3), demonstrating that the structural gene involved in extracellular protease production in W81 was inducible by proteinaceous substrates. Furthermore, induction studies demonstrated that extracellular protease production by wild-type W81 increased considerably in the presence of casein (Table 3). In this study, casein was used in experiments as a substitute for proteinaceous components of the fungal cell wall. This approach was appropriate since a similar induction of extracellular protease production occurred when strain W81 and its protease-positive mutants were exposed to autoclaved Py. ultimum mycelium (Table 3).

Early implementation of biocontrol mechanisms is required for effective control of Pythium spp. as sporangia of the fungus respond quickly to seed exudates (Nelson et al., 1988), leading to plant infection within hours of sowing (Stasz et al., 1980). Therefore, the observation that compounds exuded by the pathogen or present in the cell wall can induce extracellular protease production in W81 and its mutants suggests that the mutants W81M3 and W81M4 overproducing extracellular protease may confer increased protection to sugar beet against Pythium spp. when compared with the wild-type. Inoculation of seeds with W81, W81M3 or W81M4 resulted in similar levels of Pythium-free seeds at $1 \mathrm{~d}$ after sowing, which is not surprising as the wild-type strain was already very effective at preventing early colonization of seeds by the fungus (Fig. 3a). However, both W81M3 and W81M4 displayed a higher disease-suppressive ability throughout the $28 \mathrm{~d}$ experiment as compared with the wild-type strain, and each of the two mutants was as effective as the cocktail of commercial fungicides (Previcur $\mathrm{N}$ and thiram) for plant protection (Fig. 3b). Such levels of plant protection were previously achieved only when using a combination of W81 and Ps. fluorescens F113Rif (Dunne et al., 1998).

Overproduction of an inducible extracellular protease in $T$. harzianum resulted in reduced growth rate of the biocontrol fungus (Flores et al., 1997). In the case of W81, however, wild-type and mutants displayed the same growth rate in vitro (Table 2) and a similar ability to colonize the rhizosphere of sugar beet in soil microcosms (data not shown). Therefore, the construction of W81M3 and W81M4 by transposon mutagenesis had no obvious negative effect in terms of their 
ecological fitness in the rhizosphere. Moreover, the increase in biocontrol did not result from higher populations of the inoculants in the rhizosphere. In conclusion, the approach used in this study to develop improved biocontrol strains by increasing the production of the extracellular serine protease in S. maltophilia W81 was substantiated by significant enhancement in the suppression of Pythium-mediated dampingoff of sugar beet in soil microcosms.

\section{ACKNOWLEDGEMENTS}

The authors thank Pat Higgins and Liam Burgess for technical assistance. We are also grateful to A. Milcamps (DOE Plant Research Laboratory, MSU) for useful discussion and Tadhg O'Sullivan (Dept of Microbiology, UCC), Abdallah Magbouls and Therese Uniak-Lowe (Dept of Food Chemistry, UCC) for advice on enzyme purification. This work was supported in part by grants awarded by the Irish Science and Technology Agency Forbairt (SC-96-349 and SC-98-261) and the Biotechnology programmes of DGXII of the European Commission (BIO2-CT92-0084, BIO2-CT93-0196, BIO2-CT930053, BIO2-CT94-3001, BIO4-CT96-0027, BIO4-CT96-0181, FMRX-CT96-0039, BIO4-CT97-2227 and BIO4-CT98-0254) to F.O'G. and by the US Department of Energy (DE-FG 0290ER20021) and the NSF Center for Microbial Ecology (DIR 8809640) to F. J.de B.

\section{REFERENCES}

Agrios, G. N. (1997). Plant Pathology, 4th edn. San Diego, CA: Academic Press.

Bangera, M. G. \& Thomashow, L. S. (1999). Identification and characterization of a gene cluster for synthesis of the polyketide antibiotic 2,4-diacetylphloroglucinol from Pseudomonas fluorescens Q2-87. J Bacteriol 181, 3155-3163.

Becker, J. O. \& Cook, R. J. (1988). Role of siderophores in suppression of Pythium species and production of increased growth response of wheat by fluorescent pseudomonads. Phytopathology 78, 778-782.

Becker, J. O. \& Schwinn, F. J. (1993). Control of soil-borne pathogens with living bacteria and fungi: status and outlook. Pestic Sci 37, 355-363.

Berg, G., Marten, P. \& Ballin, G. (1996). Stenotrophomonas maltophilia in the rhizosphere of oilseed rape: occurrence, characterisation and interaction with phytopathogenic fungi. Microbiol Res 151, 19-27.

Berg, G., Marten, P. \& Bahl, H. (1998). Population dynamics of bacteria including antifungal species in the rhizosphere of oilseed rape during its life cycle. Arch Phytopathol Plant Protect 31, 215-224.

Boller, T. \& Mauch, F. (1988). Colorimetric assay for chitinase. Methods Enzymol 161, 430-435.

Bollet, C., Davin, R. A. \& De Micco, P. (1995). A simple method for selective isolation of Stenotrophomonas maltophilia from environmental samples. Appl Environ Microbiol 61, 1653-1654.

Boonchan, S., Britz, M. L. \& Stanley, G. A. (1998). Surfactantenhanced biodegradation of high molecular weight polycyclic aromatic hydrocarbons by Stenotrophomonas maltophilia. Biotechnol Bioeng 59, 482-494.

Boyer, H. W. \& Roulland-Dussoix, D. (1969). A complementation analysis of restriction and modification in Escherichia coli. J Mol Biol 41, 459-472.
Carroll, H., Moënne-Loccoz, Y., Dowling, D. N. \& O'Gara, F. (1995). Mutational disruption of the biosynthesis genes coding for the antifungal metabolite 2,4-diacetylphloroglucinol does not influence the ecological fitness of Pseudomonas fluorescens F113 in the rhizosphere of sugarbeets. Appl Environ Microbiol 61, 3002-3007.

Cook, R. J. (1993). Making greater use of introduced microorganisms for biological control of plant pathogens. Annu Rev Phytopathology 31, 53-80.

Cook, R. J., Thomashow, L. S., Weller, D. M., Fujimoto, D., Mazzola, M., Bangera, G. \& Kim, D. S. (1995). Molecular mechanisms of defence by rhizobacteria against root disease. Proc Natl Acad Sci U S A 92, 4197-4201.

Cronin, D., Moënne-Loccoz, Y., Dunne, C. \& O'Gara, F. (1997). Inhibition of egg hatch of the potato cyst nematode Globodera rostochiensis by chitinase-producing bacteria. Eur J Plant Pathol 103, 433-440.

Delany, I., Sheehan, M. M., Fenton, A., Bardin, S., Aarons, S. \& O'Gara, F. (2000). Regulation of production of the antifungal metabolite 2,4-diacetylphloroglucinol in Pseudomonas fluorescens F113: genetic analysis of $p h l F$ as a transcriptional repressor. Microbiology 146, 537-543.

Dietrich, S. M. C. (1973). Carbohydrates from the hyphal walls of some oomycetes. Biochim Biophys Acta 313, 95-98.

Ditta, G., Stanfield, S., Corbin, D. \& Helinski, D. R. (1980). Broad host range DNA cloning system for gram-negative bacteria: construction of a gene bank of Rhizobium meliloti. Proc Natl Acad Sci U S A 77, 7347-7351.

Dowling, D. N. \& O'Gara, F. (1994). Metabolites of Pseudomonas involved in the biocontrol of plant disease. Trends Biotechnol 12, 133-141.

Dowling, D. N., Sexton, R., Fenton, A., Delany, I., Fedi, S., McHugh, B., Callanan, M., Moënne-Loccoz, Y. \& O'Gara, F. (1996). Iron regulation in plant-associated Pseudomonas fluorescens M114: implications for biological control. In Molecular Biology of Pseudomonads, pp. 502-511. Edited by T. Nakazawa, K. Furukawa, D. Haas \& S. Silver. Washington, DC: American Society for Microbiology.

Dunne, C., Delany, I., Fenton, A., Lohrke, S., Moënne-Loccoz, Y. \& O'Gara, F. (1996). The biotechnology and application of Pseudomonas inoculants for the biocontrol of phytopathogens. In Biology of Plant-Microbe Interactions, pp. 441-448. Edited by G. Stacey, B. Mullin \& P. M. Gresshoff. St Paul, MI: International Society for Molecular Plant-Microbe Interactions.

Dunne, C., Delany, I., Fenton, A. \& O'Gara, F. (1997a). Mechanisms involved in biocontrol by microbial inoculants. Agronomie 16, 721-729.

Dunne, C., Crowley, J. J., Moënne-Loccoz, Y., Dowling, D. N., de Bruijn, F. J. \& O'Gara, F. (1997b). Biological control of Pythium ultimum by Stenotrophomonas maltophilia W81 is mediated by an extracellular proteolytic activity. Microbiology 143, 3921-3931.

Dunne, C., Moënne-Loccoz, Y., McCarthy, J., Higgins, P., Powell, J., Dowling, D. N. \& O'Gara, F. (1998). Combining proteolytic and phloroglucinol-producing bacteria for improved biocontrol of Pythium-mediated damping-off of sugar beet. Plant Pathol 47, 299-307.

Fedi, S., Tola, E., Moënne-Loccoz, Y., Dowling, D. N., Smith, L. M. \& O'Gara, F. (1997). Evidence for signalling between the phytopathogenic fungus Pythium ultimum and Pseudomonas fluorescens F113: P. ultimum represses the expression of genes in P. fluorescens F113, resulting in altered ecological fitness. Appl Environ Microbiol 63, 4261-4266. 
Fenton, A. M., Stephens, P. M., Crowley, J., O’Callaghan, M. \& O'Gara, F. (1992). Exploitation of gene(s) involved in 2,4diacetylphloroglucinol biosynthesis to confer a new biocontrol capability to a Pseudomonas strain. Appl Environ Microbiol 58, 3873-3878.

Flores, A., Chet, I. \& Herrera-Estrella, A. (1997). Improved biocontrol activity of Trichoderma harzianum by overexpression of the proteinase-encoding gene prb1. Curr Genet 31, 30-37.

Geremia, R. A., Goldman, G. H., Jacobs, D., Ardiles, W., Vila, S. B., Van Montagu, M. \& Herrera-Estrella, A. (1993). Molecular characterisation of the proteinase-encoding gene, prb1, related to mycoparasitism by Trichoderma harzianum. Mol Microbiol 8, 603-613.

Giesler, L. J. \& Yuen, G. Y. (1998). Evaluation of Stenotrophomonas maltophilia strain C3 for biocontrol of brown patch disease. Crop Protect 17, 509-513.

Handelsman, J. \& Stabb, E. V. (1996). Biocontrol of soilborne plant pathogens. Plant Cell 8, 1855-1869.

Haran, S., Schickler, H. \& Chet, I. (1996). Molecular mechanisms of lytic enzymes involved in the biocontrol activity of Trichoderma harzianum. Microbiology 142, 2321-2331.

Jacobi, M., Winkelmann, G., Kaiser, D., Kempter, C., Jung, G., Berg, G. \& Bahl, H. (1996). Maltophilin: a new antifungal compound produced by Stenotrophomonas maltophilia R3089. J Antibiot 11, 1101-1104.

Jeffers, S. N. \& Martin, S. B. (1986). Comparison of two media selective for Phytophthora and Pythium spp. Plant Dis 70, 1038-1043.

Keel, C. \& Défago, G. (1997). Interactions between beneficial soil bacteria and root pathogens: mechanisms and ecological impact. In Multitrophic Interactions in Terrestrial Systems, pp. 27-46. Edited by A. C. Gange \& V. K. Brown. London: Blackwell Scientific Publications.

Kragelund, L., Christoffersen, B., Nybroe, O. \& de Bruijn, F. J. (1995). Isolation of $l u x$ reporter gene fusions in Pseudomonas fluorescens DF57 inducible by nitrogen or phosphorus starvation. FEMS Microbiol Ecol 17, 95-106.

Lorito, M., Peterbauer, C., Hayes, C. K. \& Harman, G. E. (1994). Synergistic interaction between fungal cell wall degrading enzymes and different antifungal compounds enhances inhibition of spore germination. Microbiology 140, 623-629.

Lugtenberg, B. J. J. \& Dekkers, L. C. (1999). What makes Pseudomonas bacteria rhizosphere competent? Environ Microbiol 1, 9-15.

McKellar, R. C. (1981). Development of off-flavour in ultra-high temperature and pasteurized milk is a function of proteolysis. J Dairy Sci 64, 2138-2145.

Milcamps, A. \& de Bruijn, F. J. (1999). Identification of a novel nutrient-deprivation-induced Sinorhizobium meliloti gene $(h m g A)$ involved in the degradation of tyrosine. Microbiology 145, 935-947.

Milcamps, A., Ragatz, D. M., Lim, P. O., Berger, K. A. \& de Bruijn, F. J. (1998). Isolation of carbon- and nitrogen-deprivation-induced loci of Sinorhizobium meliloti 1021 by Tn5-luxAB mutagenesis. Microbiology 144, 3205-3218.

Mitchell, R. \& Hurwitz, E. (1965). Suppression of Pythium debaryanum by lytic rhizosphere bacteria. Phytopathology 55, 156-158.

Moënne-Loccoz, Y., Powell, J., Higgins, P., Britton, J. \& O'Gara, F. (1998). Effect of the biocontrol agent Pseudomonas fluorescens F113 released as sugarbeet inoculant on the nutrient contents of soil and foliage of a red clover rotation crop. Biol Fertil Soils 27, 380-385.

Moënne-Loccoz, Y., Naughton, M., Higgins, P., Powell, J., O'Connor, B. \& O'Gara, F. (1999). Effect of inoculum preparation and formulation on survival and biocontrol efficacy of Pseudomonas fluorescens F113. J Appl Microbiol 86, 108-116.

Nelson, E. B., Harman, G. E. \& Nash, G. T. (1988). Enhancement of Trichoderma induced biological control of Pythium seed rot and pre-emergence damping-off of peas. Soil Biol Biochem 20, 145-150.

Nielsen, M. N., Sorensen, J., Fels, J. \& Pedersen, H. C. (1998). Secondary metabolite- and endochitinase-dependent antagonism towards plant-pathogenic microfungi of Pseudomonas fluorescens isolates from sugar beet rhizosphere. Appl Environ Microbiol 64, 3563-3569.

O'Sullivan, D. J. \& O'Gara, F. (1992). Traits of fluorescent Pseudomonas spp. involved in suppression of plant root pathogens. Microbiol Rev 56, 662-676.

Palleroni, N. J. \& Bradbury, J. F. (1993). Stenotrophomonas, a new bacterial genus for Xanthomonas maltophilia (Hugh 1980) Swings et al., 1983. Int J Syst Bacteriol 43, 606-609.

Sambrook, J., Fritsch, E. F. \& Maniatis, T. (1989). Molecular Cloning: a Laboratory Manual, 2nd edn. Cold Spring Harbor, NY : Cold Spring Harbor Laboratory.

Scher, F. M. \& Baker, R. (1982). Effect of Pseudomonas putida and a synthetic iron chelator on induction of soil suppressiveness to Fusarium wilt pathogens. Phytopathology 72, 1567-1573.

Schnider, U., Keel, C., Voisard, C., Défago, G. \& Haas, D. (1995). Tn5-directed cloning of $p q q$ genes from Pseudomonas fluorescens CHA0: mutational inactivation of the genes results in overproduction of the antibiotic pyoluteorin. Appl Environ Microbiol 61, 3856-3864.

Stasz, T. E., Harman, G. E. \& Marx, G. A. (1980). Time and site of infection of resistant and susceptible germinating pea seeds by Pythium ultimum. Phytopathology 70, 730-733.

Thrane, C., Tronsmo, A. \& Funck Jensen, D. (1997). Endo-1,3- $\beta$ glucanase and cellulase from Trichoderma harzianum: purification and partial characterization, induction of and biological activity against plant pathogenic Pythium spp. Eur J Plant Pathol 103, 331-344.

Twinning, S. (1984). Fluorescein isothiocyanate-labelled casein assay for proteolytic enzymes. Anal Biochem 143, 30-34.

Van Wees, S. C. M., Pieterse, C. M. J., Trijssenaar, A., Van 't Westende, Y. A. M., Hartog, F. \& Van Loon, L. C. (1997). Differential induction of systemic resistance in Arabidopsis by biocontrol bacteria. Mol Plant-Microbe Interact 10, 716-724.

Wolk, C. P., Cai, Y. \& Panoff, J. M. (1991). Use of a transposon with luciferase as a reporter to identify environmentally responsive genes in a cyanobacterium. Proc Natl Acad Sci U S A 88, $5355-5359$.

Received 25 October 1999; revised 19 April 2000; accepted 8 May 2000. 